\title{
Is there a future for research?
}

Onerous and unprecedented regulation of research, and financial difficulties, have given many researchers the impression that fruitful applications will now come only slowly, but others believe they flow too thick and fast.

WhateVer happened to the golden age of science, when research was assured of unstinted support? Has public enchantment with the research enterprise melted away and, if so, why? Is the pace of innovation now so much more rapid than that of human evolution by natural selection that bewilderment is unavoidable?

These were some of the questions taken as starting-points for a discussion last weekend, organized by the Ditchley Foundation at its jewel of a manor-house in Oxfordshire, on the future of science and technology. Most often, Ditchley conferences, which are strongly AngloAmerican, are overwhelmed by diplomats and politicians (although technical subjects such as arms control and greenhouse warming get a hearing).

Last weekend's meeting was unusual because of the presence of many influential researchers (Sidney Drell from Stanford, Joshua Lederberg from the Rockefeller University and Sir Walter Bodmer from the Imperial Cancer Research Laboratories, for example), research administrators and science advisers (including Professor Henry Durand from Paris, Dr Geraldine Kenney-Wallace from Ottawa, $\mathrm{Mr}$ J.W. Fairclough from the British Cabinet Office, Dr William T. Golden from the New York Academy of Science, Dr Hans-Peter Lorenzen from Bonn and Dr V. Ramalingaswami, now at UNICEF), politicians (Dr Jeremy Bray, MP, and Mr John Brademas, the Democratic congressman now turned president of New York University), academics (Professor Ashton Carter from Harvard University, Sir John Kingman, vice-chancellor of the University of Bristol, Professor Joseph Nye from Harvard University and Dr Robert Rosenzweig, president of the Association of American Universities) and others, such as $\mathrm{Mr}$ Peter Benton (director-general of the British Institute of Management, Mr John Chowcat from the (British) Manufacturing, Science and Finance Union and $\mathrm{Mr}$ Leonard $\mathrm{D}$. Schaeffer, president of Blue Cross of California. The chairman was Dr David A. Hamburg, president of the Carnegie Corporation of New York, which last year set up a commission on Science, Technology and Government. (This list is not complete.) The reporting rules are that one may say what was said, but not who said it, which means that what follows may be larded with hindsight.

So was there a golden age, and has it vanished? People are inevitably divided. Some note that the world at large has always been sceptical of as well as enthusiastic for innovation, while even nowbeneficent innovations have been tightly regulated in the public interest. Others remark that the belief, widespread after the Second World War, that everything had become possible, was infectious, but was dispelled by the concealment by governments and technical people themselves of the hazards of new technology.

But attitudes towards new technology generally seem to be curiously patchy. The world at large has taken motor cars to its heart and the unsung benefits of telecommunications satellites and weather satellites for granted, but is cool about the US shuttle and sceptical of the US space station, perhaps because it is a project without a purpose. There seems to be a general opinion that progress will eventually hang on international collaboration, but the importance of man in space remains disputable.

The reasons why France alone among countries generating electricity from uranium appears to have avoided antinuclear protests fascinate those from elsewhere; good management is the simplest explanation, although the Commissariat à l'Energie Atomique has only recently adopted the practice of giving news of anything untoward that happens at its nuclear plants in the hope of engendering a sense that not all accidents are catastrophes. But there are clouds on the horizon. The green party that did well in France as in Britain in last month's elections to the European Parliament is already calling for a halt to nuclear construction (the last reactors in the current French programme will be commissioned in 1994) and for a reduction of nucleargenerating capacity to make the export of nuclear electricity impossible. And, as one participant said, "Just wait until you have a major accident!"

The new biology is the chief source of public passion. The research community seems to have won no credit for the Asilomar conference and the voluntary moratorium on research that followed. Genetic manipulation and embryology have become the only fields in which enquiry may be forbidden (as distinct from research with animals, where it is the procedures that are regulated). Some plead that legislation in the field should be flexible enough to accommodate discovery and the greater sense of security that may follow, but governments, responding to their electors' opinions, are determined that research will be done with 'care', even if that means that the pace of development is slowed. There seems a gulf of understanding between biologists and governments (not to mention the public) about the human genome project (which in due course will create ethical problems for genetic counsellors, but which meanwhile tends to be lumped in with genetic manipulation). It hardly helps that some describe the project as "biology's porkbarrel".

What remedies are there? Better public understanding is a goal for everybody, but there is much doubt of what is intended. The ideal would be an educational system producing literate populations of democratic voters, but the need is too urgent for those now in kindergarten to join their ranks. Meanwhile, secondary schools, even if hampered from teaching as much science proper as they would wish, have a responsibility to give students a sense of what science and technology are like that understanding is always incomplete and that its application is almost always followed by unexpected consequences.

Estimating and evaluating risk requires special attention. One speaker (a mathematician) warned that calculations of the risk of accidents in, say, the operation of nuclear reactors yielding estimates such as 'one in $10^{\prime}$ 'should be generally disbelieved, on the grounds that the probabilities multiplied together in the process are not usually as independent as they should be. More practically, seeking to make machines safer by elaborating parallel control systems may induce a sense of complacency among operators.

But public understanding is not the only need. The research community's reputation for probity may be damaged by the recent flurry of scandals about dishonest publications. Some pleaded that the seriousness of this danger should be more openly acknowledged. Researchers as 'false prophets' present more difficult questions: the benefits of nuclear energy and of the Strategic Defense Initiative may have been oversold (and the claims on behalf of cold fusion may yet leave a black mark on public opinion), but it will be a bad business if people's enthusiasm for their research and its significance must be self-censored to be sober. Is not science also fun?

John Maddox 